just indicated, the whole of the proteids, and together with them all antitoxic virtue, is absent from the filtrate. Toxin, on the other hand, the molecular size of which is of the albumose order, is not held back by the filter. Corresponding results are obtained with the toxin and antitoxin of snake venom.

Coming now to the second question, the nature of the antagonism between these substances, we find that it is one on which a difference of opinion has hitherto been held. Behring, Ehrlich, Kanthack and Brodie maintain that the antagonism is of a chemical nature, and that the antitoxin neutralises the toxin much in the same way that an alkali neutralises an acid. Buchner, Calmette, Metchnikoff, and others, on the other hand, regard the action as an indirect one, operating in some way through the medium of the cells of the organism. The work on which such an assertion rests may be instanced by a typical experiment of Calmette's on cobra poison. The venom is not attenuated by heating its solutions to $68^{\circ} \mathrm{C}$. for ten minutes; the antitoxin is, however, completely destroyed by this treatment. Mixtures of cobra toxin and antitoxin, which produced no symptoms when injected into rabbits, killed similar rabbits in a few hours if, after the mixture had remained in contact for ten minutes, it were heated to $68^{\circ} \mathrm{C}$. for another ten minutes before injecting; hence the conclusion that the toxin and antitoxin do not interact in vitro, but only in corpore, and therefore that the action cannot be explained as a simple chemical operation between the two.

Such an experiment is not, however, conclusive ; it can be easily repeated with the same result, but the source of fallacy is that it takes no account of the factor-time. Every chemical operation has a certain definite velocity coefficient, and the rapidity of action under any circumstances when the reacting compounds are in solution depends upon this coefficient, and also upon the product of the active masses of the compounds present. Temperature will also exercise an important influence.

Remembering the high molecular weight of both toxin and antitoxin, one would a priori expect the velocity coefficient of any reaction between them to be a high one, and in addition the solution would contain relatively few molecules; so it is not surprising that any chemical opcration should occupy a very appreciable time. If the two substances are left in contact for more than Calmette's ten minutes, the substances completely neutralise each other in ritro.

The following table gives a summary of Martin and other, with proportion of active masses constant. On reading any vertical line, the influence of varying proportions of active masses with time of operation constant is indicated. The thick line separates off the fatal results from those in which the rabbits lived. All other factors were kept constant. The solutions were mixed in the varying proportions, and stood at laboratory temperature $\left(20^{2}-23^{3} \mathrm{C}\right.$.). At stated intervals, by a stop-watch, portions were pipetted off, and the reaction terminated by rapidly raising the temperature to $68^{\circ} \mathrm{C}$. in a water bath. They were kept at this temperature for ten minutes; cooled, and kept for injection.

Fxactly corresponding results were obtained with diphtheria toxin and antitoxin; and we may conclude by quoting an experiment with these substances, in which a different modus operandi was adopted. Similar experiments have been recently performed by Brodie, and published in his Arris and Gale lectures; his results completely coincide with those of Martin and Cherry.

A solution of toxin containing cight fatal doses per kilogram of guinea-pig in each c.c. was mixed with sufficient antitoxin to more than completcly neutralise all the toxin. This mixture was allowed to remain in contact at $30^{3} \mathrm{C}$. for two hours, and then filtered through the gelatin filter. Varying quantities of the filtrate were injected into guinea-pigs up to nearly 4 c.c. per kilogram of body-weight ; that is, a quantity originally containing thirty-two fatal doses. The filtrate was quite innocent. The guinea-pigs suffered no inconvenience, and gained weight while under observation in small cages. The injections produced no local œdema.

If the toxin had remained unaffected beside the anti. toxin, there was nothing to prevent it passing through the filter in virtue of its relatively small molecular size. As, however, it did not do so, we can only conclude that it had entered into some sort of chemical relationship with the relatively large molecules of the antitoxin during their sojourn together prior to filtration.

IV. D. H.

\section{A MINISTER OF EDUCATION AT LAST.}

THE Duke of Devonshire made a most important speech on Monday in introducing a new IBill relating to Secondary Education.

The Bill really seeks to reconstruct the whole of our haphazard organisation dealing with Education, Science and Art ; whether the recommendation will do harm or

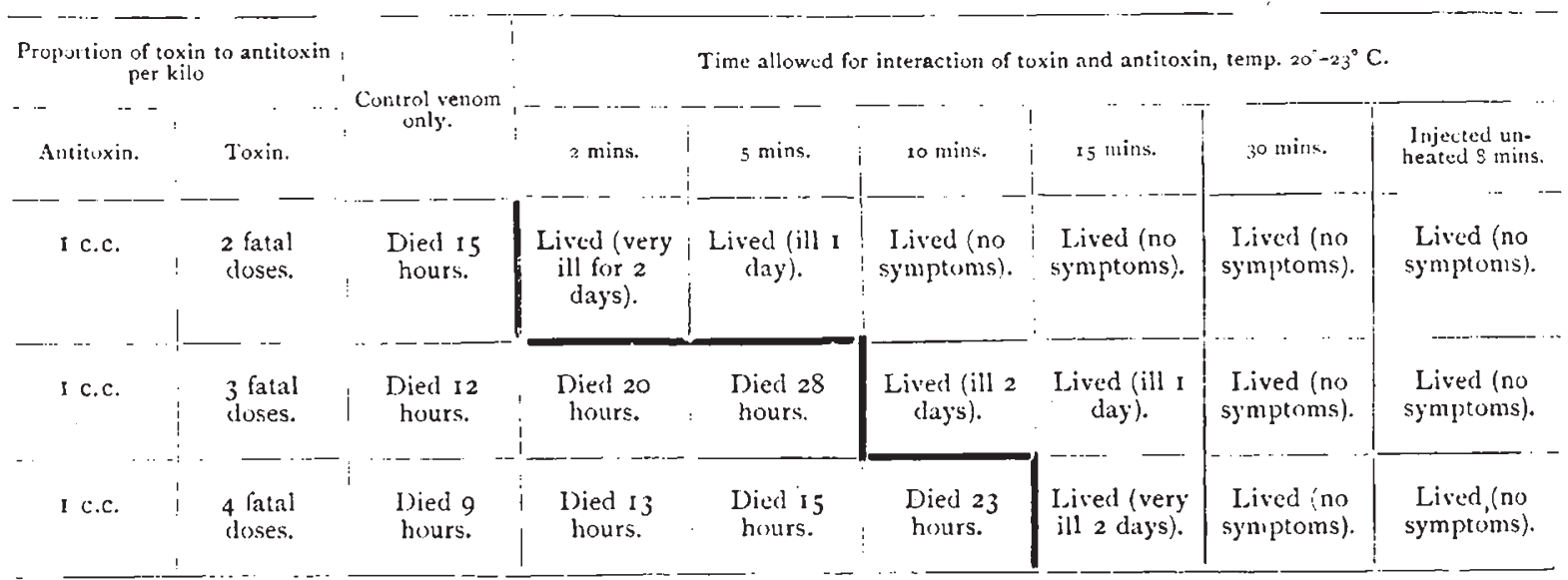

Cherry's principal experiments with snake venom. On reading along any horizontal line will be seen the influence upon the result of the time during which the toxin and antitoxin were allowed to operate upon each NO. I jOI VOL. 58] grood depends upon the reconstructors, and who they are does not appear. It should, howerer, be a matter of congratulation that the lamentable condition of our present want of system, which has been known to educa- 
tionists for many a long year, is at last recognised by those who are responsible for its inefficiency.

We gather from the Times, (theBill has not yet been published) that the Government has now come " to the natural and logical conclusion, a conclusion which almost every other civilised nation has reached long ago, that there should be a comprehensive educational department dealing, generally speaking, with our national education as a whole, and presided over by a real Minister of Education. $\therefore$. There is to be a Board of Education, as there is a Board of Trade and a Local Government Board, and the new Board is, like these, to have a responsible Minister at its head, the President of the Board. Under him, the present Education Department and the Science and Art Department are to be amalgamated into one office, with one Secretary; and many of the educational powers of the Charity Commissioners are to be at once taken over by the new Board."

We reprint the latter part of the Duke's speech.

The Bills I have to propose are of an extremely limited character. The first proposes to create a central educational authority. Much that is done in it could properly be done by an administrative order by the Government; but in order to obtain Parliamentary sanction to the policy which we propose, we have thought it more desirable to embody our proposals in a Bill. At the present time the President of the Council or the Vice-President of the Council is for many purposes the Minister of Education; but under them are what are virtually two distinct Boards, the Education Department and the Department of Science and Art. We propose to bring these two Departments together to make out of them one office under the control of one permanent Secretary. We propose to put an end to the Committee of Council and to the office of Vice-President of the Committee of Council. We propose to create a Board of Education on the model of the Board of Trade, the Local Government Board, and the Board of Agriculture. The President and the Vice-President, or the President alone, of this Board may be appointed. If the Education Minister should be in the House of Lords, it is provided that the President of the Council will be the President of the Board, and he will be represented by the Vice-President in the House of Commons. If the Minister of Education should be in the House of Commons he will have the office of President, and will have no Vice-President. The Department will be represented in this House by some arrangement such as we have found practical in the case of other Departments. We think that the present time is extremely opportune for such a reorganisation of our Education Department. Next year the Secretary for the Science and Art Department retires under the age rule. The office which he holds is one that has never escaped criticism, and perhaps the strength of Sir John Donnelly's convictions and the energy with which he has supported them has exposed him to even a larger share of criticism than some of his predecessors. I think it only due to Sir John Donnelly to state that the Government has never possessed a more devoted public servant, and that, under conditions extremely difficult, I believe the Department has, under his administration, taken part in the very great development both of scientific and artistic training. But the changed conditions of education, the growth of the Department itself, the growing conviction for a better and a more special technical training for our people-a conviction that has found expression in the Technical Instruction Act-all these have rendered a revision of the scope and character of the Department absolutely necessary at the present time. I believe that that revision will be greatly assisted if we are able to obtain, what we are asking Parliament to give, sanction for the establishment of one central responsible department which should be charged with the supervision of secondary as well as elementary education, and of all the agencies appertaining to both. The Bill, I need hardly say, will not contain the details of the proposed reorganisation. They cannot well be promulgated until Parliament has given its sanction to the principle of the establishment of a central authority. But I may say that the reorganisation will not necessarily be confined to the Department of Science and Art. It would be entirely a mistake to suppose that there is any intention of simply merging the Department of Science and Art into that of Education. The Education Department itself under our plan will require some reorganisation. Some of the duties performed by the Education Department - such as those which relate to training colleges, to training pupil teachers, to the higher-grade schools-are pertaining more to secondary rather than to elementary education; and it may very well be that it will be found expedient to group those functions which are now discharged by the Education Department and others which are now discharged by the Science and Art Department under a Secondary Education Department proper, while a third division may possibly be charged with the supervision of the more technical branches of science and art instruction, and at the same time control and manage the Science and Art Museums which exist both in the metropolis and the provinces. These details of reorganisation have, of course, to be worked out by the departments concerned and by the Treasury after the work which will be undertaken in anticipation of the approval which we hope we may obtain to the proposals we are now making. I do not know whether there are any of your lordships House who are interested in the subject of economy. It is said, I believe, that no one in the House of Commons cares about economy except the Chancellor of the Exchequer and his predecessor. But I do not think that this proposed reorganisation need necessarily lead us, or ought to lead us, to any increased expenditure on administration. It is, of course, impossible to say what this Parliament or future Parliaments may think fit to spend directly on secondary technical, scientific, or artistic education. But, so far as administration is concerned, which is all we are dealing with at present, I see no reason why this arrangement should lead to any increased expenditure. I rather think it will tend to economy. Already by the transfer of training in elementary schools from the Science and Art to the Education Department a very considerable saving has been effected; and in my opinion the system under which grants in aid to science and art teaching are now dispensed is, in consequence of the rapid and unforeseen extension of the systema system which has been steadily developed from small beginnings indeed-so cumbrous and complicated, and therefore so costly, that I should be very much disappointed if by a more systematic and scientific rearrangement of duties a very considerable economy cannot be brought about. I have said that a great deal of what we proposed to do could be done simply by an administration order to which the sanction of Parliament might be given when the estimates are presented; but, as I have said, we thought it better to embody the main principles in a Bill. But one portion of the duties which we propose to transfer under the Education Department cannot be transferred without legislation. I refer to the supervision of endowed schools under the schemes which have been promoted by the Charity Commissioners. Logic and symmetry may perhaps appear to require that the whole of the powers of the Charity Commissioners, so far as they relate to educational endowments, should be transferred to the Education Department. But the subject of endowments is so delicate, the distinction between charitable and educational objects and charitable trusts, the extent to which the necessities of special cases are to be regarded, the sectarian questions, which they involve are all so difficult and controversial in character that we have hesitated to propose to transfer all such questions from a quasi-judicial to a political authority. Under this Bill, there. fore, the administration of charitable trusts and the framing of trusts under the Endowed Schools Act will remain untouched, except that an instruction will be given to the Charity Commissioners to frame schemes, so far as they are educational, in consultation with the Education Board, and the Education Board will have power to promote other schemes when required. All these schemes contain a provision with regard to the educational examination of the schools, and the result of that examination is reported to the Charity Commission. They also institute from time to time an administrative inspection of their own, as to the management of the funds of the school and other matters. The educational examination and the administrative inspection, so far as it relates to educational matters, will be transferred to the new Department. In other respects the present powers of the Charity Commissioners will not be interfered with by the Bill. But for the first time a most important part of our educational system will be brought under the cognisances, and to a certain extent under the guidance, of the responsible Minister of Education. The Royal Cummission laid considerable stress on the constitution of an educational council with consultative and certain administrative powers. We have

NO. I 5 OI, VOL. 58] 
been unable to accept those recommendations as a whole. For the purpose of forming and maintaining a registry of teachers a separate and more or less independent council was necessary. A Bill for that purpose was introduced some time ago, which will be reintroduced to-day. It provides a council for this purpose only, some of whose members will be nominated by the Crown, some by the Universities, and ultimately it will contain members directly representative of the registered teachers themselves. But we have not seen our way to give to this council or to any other council statutory powers. We recognise, however, that the advice of educational experts may be of great value to the Board of Education. We have taken power to authorise the President of the Board of Education to appoint an educational committee to advise the Board on such matters as may be referred to it. Such a committee in all probability will be largely founded upon the registration council. In our opinion it would only tend to hamper the responsibility of a Minister if a consultative council were appointed by statute and endowed with statutory powers ; in our opinion the Minister must be responsible for the choice of his advisers as well as the action which he takes upon that advice. While it is desirable, almost necessary, that the registration council should have a fixed and permanent character, we thought it desirable to reserve complete discretion to the Minister as to the choice of his advisers. I have endeavoured to explain what these Bills contain. It may appear to be a somewhat rash act to submit proposals of this character to be exposed to discussion and criticism during the long months of a comparatively unoccupied recess. It may be so, but for my part I can only say that I welcome the fullest discussion and criticism. I welcome discussion on a subject in which, in my opinion, too little interest has been hitherto felt by the general public as distinguished from professional experts, and I only trust that these proposals may receive very full discussion and criticism. I have no doubt that they will be condemned by some on account of their incompleteness; I have admitted that they are incomplete, and incomplete on a vital and essential point, but $I$ have endeavoured to show that we have not been insensible to the importance or the urgency of that portion of the question, which we propose at present to postpone. If we have postponed it, it is because we are convinced that the constitution, preliminarily or concurrently, of a strong central authority is necessary for the equally important, perhaps more important, object-the creation of strong local authorities also. If the discussion which follows the introduction of this measure shows that we have over-rated the diffculties which I think still exist in the constitution of satisfactory local authorities, it may still be possible in another session to enlarge the scope of this Bill. But, however that may be, we may feel confident that these limited proposals, standing even alone, will be an important step in the direction of placing our national education upon a sounder and more satisfactory basis.

\section{NOTES.}

Prof. E. Kay Lankester has been appointed to succeed Sir William Flower as Director of the Natural History Museum at South Kensington.

THE fourth International Congress of Physiologists will assemble at Cambridge on Monday, August 22, and will hold its meetings each morning and afternoon from Tuesday, $23 \mathrm{rd}$, to Friday, 26th, inclusive. The Congress has for its object the advancement of physiology by affording physiologists of various nationalities an opportunity of personally bringing forward experiments, and of exchanging and discussing their views together, and of becoming personally acquainted one with another. The languages to be recognised as official at the Congress are English, French, and German. Membership is open to (I) representatives of physiology in the persons of professors and their assistants ; 2 members of physiological and similar purely scientific societies, as for example, American Physiological Society; the Physiological Society, England; Société de Biologie, Paris; Physiologische Gesellschaft, Berlin; (3) ladies and gentlemen who are proposed by a National Committee. Members will be afforded all possible facilities for experimental demonstrations, as well as for the exhibition of preparations and of scientific apparatus. In connection with the Congress there will be an exhibition of physiological apparatus. Those who attend the Congress, and all directors of physiological institutes, as well as instrument-makers recommended by the above, are invited to send exhibits. The exhibition will remain open from Monday, the 22nd, to Saturday, August 27, inclusive. A large number of British, American and Continental physiologists have notified their intention to be present. The organising Committee of the Congress is constituted as follows :--M. Foster, President; M. Blix, H. P. Bowditch, A. Dastre, P. Heger, H. Kronecker, W. Kühne, A. Mosso, W. Wedensky, with L. Fredericq, P. Gritzner and C. S. Sherrington, Secretaries. Further information concerning the local arrangements for the Congress can be obtained from Dr. L. E. Shore, St. John's College, Cambridge.

THE Government of the Congo Independent State has, it is stated, just sanctioned an important measure for the advancement of scientific knowledge on the Congo. The despatch, last spring, of the expedition under Lieut. Lemaire was a commencement in this direction, but, whereas his explorations will be chiefly in the Tanganyika region, the new measure will apply to the whole of the State. Twenty posts which are to form the centres of observation, and also the bases for the collection of flora, fauna, and mineralogical specimens, have been decided upon, and are now being carefully organised under the supervision of the proper officers at Brussels. As soon as the posts are in working order, a publication will be issued at Brussels for the purpose of recording the results of these experiments. It will be issued every six weeks, under the title of "Scientific Annals."

Mr. W. Harcourt-Bath has recently returned to England with a large collection of insects obtained in the Himalayas of Sikkim and Thibet, many of which were procured at great altitudes among the snow.

A REMARKABLY fine specimen of the gigantic centipede (Scolopendra gigas) may be now seen in the Zoological Society's Insect House. It is not, perhaps, quite full grown, but measures about eight inches in length. It is fed principally on small mice, which it devours with alacrity. This specimen was captured in Trinidad, and forwarded to the Society by Mr, R. R. Mole, of Port-o-Spain.

The expedition sent out to the Galapagos Islands, at the suggestion of the Hon. Walter Rothschild, last year brought home a fine series of living tortoises, which have been recently deposited in the Zoological Society's Gardens. There are in all fifty-two specimens belonging to the group of large land tortoises namely thirty-three of Testudo vicina from the south part of Albemarle Island, and nineteen of Testudo ephippium from Duncan Island. These have been placed in the old Tortoise House in the North Garden, and feed greedily on cabbages. The interesting account of the giant tortoises of the Galapagos, given by Darwin in his " Naturalists' Journal," will be in every one's recollection.

The Committee appointed by the Board of Trade a yearago, to consider and advise upon the means of obtaining and publishing information as to opportunities for the introduction and development of British home trades in the various districts in which we have official representatives, have adopted their report. As to the means of obtaining further commercial information, it is suggested that the most economical course would be to send out experts periodically to make inquiries and to report upon the progress and the direction of trade. The Committee recommend the establishment of an office whose function it shall be to meet the constantly-increasing demand for prompt and accurate information on commercial matters, so

NO. I 5 O I, VOL. 58] 